\title{
Survival Strategies and Power amongst the Poorest in a West Bengal Village
}

\author{
Tony Beck
}

\section{INTRODUCTION}

Recent attention to rural indigenous technical knowledge and farming systems in South Asia and Africa has concentrated mainly on agricultural technology and small farmers; and a growing literature on the causes of and responses to famine has focused on events which drastically affect large populations. Less interest has been shown in the landless and in "everyday forms of poor people"s survival'.

Survival strategies means the activities of poor people in times of stress which they see as crucial for the continued running of their household. This focus concentrates on their own priorities, and points to activities mainly outside the 'formal economy'. In this article it does not include organised and spontaneous violent and non-violent resistance by the poor. ${ }^{1}$ In West Bengal and no doubt in India generally, exploitative and oppressive village social structure is the main cause of poverty. For the outsider the problem is not only to document this, but to decide what action to take. Power relations cannot be ignored, but neither in many cases can they be dealt with directly. Those who advocate or examine radical alternatives at village level should be aware of the moral problems of doing so as outsiders. ${ }^{2}$ The boundaries of empirical research on rural poverty by outsiders are perhaps marked by areas of organisation and cooperation by the poor. A practical focus, as in this article, can be to look for 'gaps' or 'soft areas' in the village power structure [Chambers 1983:157-63] areas already used by the poor, that can bring benefits to them by exploiting the present system, and which, strengthened in the long term, could change the balance and structure of power.

Theoretically, concentrating on poor people's priorities is an adaptation of the idea of people's history developed by British Marxist historians such as Thompson. Hill, Samuel and others. ${ }^{3}$ This involves

\footnotetext{
'For the moral and social difficulties of dealing with power at Indian village level. see Breman [1985].

${ }^{2}$ This is meant with reference to empirical research, and not other more historical or academic forms of research.

${ }^{3}$ For a similar use of such theory. on a much broader historical scale. see Watts [1983]. For use of this theory in relation to Bengal. see Van Schendel and Faraizi [1984]. and to Madras 1876-78. Arnold [1984]. My focus here is on people rather than history.
}

giving a 'worm's eye' or 'people's' view of the world. and a respect for and political sympathy with the poor as makers of their own histories.

This approach may have two possible effects. First, it can challenge a dominant view of the poor - that they are passive, irresponsible or conservaltive, and its political corollary, that poor people are there to be planned for. ${ }^{4}$ Challenging these views may change how plans are made, or even make it acceptable to propose that poor people can make their own plans. Sccond, this approach has policy implications, in particular how poor people's own strategies can be built upon and improved. In a different geographical context, Richards (1985, 1986) and Watts (1983) argued for backing and improving small farmer's indigenous agricultural strategies. Little has been written on the priorities perceived by poor rural landless people, on how they organise their lives, and how their more informal activities could be supported. To throw light on these questions, this article presents research findings from a village in West Bengal and explores their policy implications.

\section{THE VILLAGE, 'MENTAL-METRICISM' AND WHO THE POOREST ARE}

\section{(a) The Case Study Village}

Although only $40 \mathrm{~km}$ from Calcutta (or three hours by public transport) Fonogram village 5 in north 24 Parganas District remains relatively isolated. Local transport is limited, the main forms being foot and bicycle. There is a small town two and a half kilometres away which holds a twice weekly market. Most villagers do not often have the time to go further afield.

Fonogram is a Muslim village of 140 households and a population of about 830 . It is mainly agricultural, "aman' being the year's main rice crop, harvested in October/November. West Bengal as a whole has a net sown area of roughly $13.6 \mathrm{mn}$ acres and a rural population in the early 1980 s of around $40 \mathrm{mn}$ with about one third of an acre available per person (the second lowest land-person ratio in India, next to Kerala) [Bandopadhyay 1983]. Net sown area for

\footnotetext{
${ }^{4}$ For a further discussion of the political connection between ideology. planning. and the characteristics of the poor, see Beck [1988].

${ }^{5}$ A pseudonym.
} 
Fonogram is about 162 acres (according to the Census of India for 1971), so its population density is even higher than the all West Bengal figure. An estimated one third of households in Fonogram are operationally landless, and strategies for survival should be seen in the context of both scarcity and unequal holding of land.

Interviews were carried out with 22 respondent households in the winters of $1986 / 87$ and $1987 / 88$. In both these years the main part of the 'aman' crop was destroyed by flooding, which meant little work for those usually employed as agricultural labourers, damage to several of the respondents' houses and a period of general austerity (although the market price of rice, the main staple, did not increase noticeably in either year). In 1986/87 interviews were held as to how respondents were coping after the flood. A questionnaire designed from these interviews was used in $1987 / 88$ concentrating on survival, and the villagers' views on social, economic and political aspects of village life. Quantitative methods were seen to be inadequate for analysing the villagers' replies. My own findings, have, therefore, been placed in the wider context of literature on poverty and survival to draw out their representativeness.

Of the 22 households, seven were female headed (all widows) and two respondents were widowers; in all, I spoke to 12 women, three men, and seven families (husband, wife, their parents and/or their grown up children). Twenty of the households were operationally landless (five without homestead land). Employment patterns of respondents were irregular, but the primary occupations of the main household earners were as follows: ten agricultural labourers, three labourers on lorries, three sharecroppers, three factory workers, one maid, one hawker and one marginal farmer.

\section{(b) Mental-Metricism}

Sen (1983), and Kynch and Sen (1983) have pointed out some analytical difficulties in development and poverty measurement studies based on respondents' perceptions, particularly that these may differ markedly from a more objectively measurable 'reality'. Sen has suggested focusing instead on 'capabilities' or macro-level indicators of ill-or wellbeing, such as long term mortality or literacy rates. This is part of a wider debate about the quality of poverty and whether or not it has an absolute or relative core [see Sen 1983 vs Townsend 1985];.

To concentrate solely on statistical analysis of macrolevel data (or indeed similar analysis of micro-level data), however, ignores the paradigmatic. basis of collection and use of such data - that it is based, in the Indian context, on a particular, dominant view of the poor and a political ideology, that sees the poor as passive and dependent - a kind of statistical cannon fodder; and it is also to ignore the causes of poverty. Equally, such statistical analysis of macro (or micro) level data on literacy and mortality rates, for example, overlooks the 'informal economy' in which the poor operate, which is crucial to their survival, and through which they conduct a large part of their affairs. It is useful and balanced to look for ways to combine macro and micro-level statistical analysis with poor people's own perceptions and for ways in which these complement each other.

If village studies concerned with poor people's views are to be representative rather than idiosyncratic, there is a need for comparative material from which to generalise. As statistical analysis of data receives its legitimacy from its supposed accuracy, so village studies will become more credible as representative (or not) if comparable studies show similar findings (or not). Those few articles that I have come across on survival strategies in South Asia all comment on a lack of comparative material. ${ }^{6}$ However, widespread evidence of, for example, enforced changes in consumption by the poor in times of food shortage, or of share-rearing of livestock by poor families, now suggests that these priorities and actions of the poor should be taken into account when policy is being
considered.

\section{(c) Who are the Poorest?}

Drawing on recent work by Chambers [1988:17-18] and Lipton [1983 a, b, c and 1985] on the "characteristics' of the poorest, and other sources including my field work, it is possible to suggest, in an eastern South Asian context, how the poorest act and which households they are in. They are likely:

1) to be exploited in terms of receipt of wages or credit, and to be in debt;

2) to be flexible in terms of coping, using a variety of strategies and able to work at a number of jobs [see Van Schendel 1986:44; Jiggins 1986:11; Caldwell 1986:682,691; Cain 1977:209];

3) to be resilient and active in areas concerned with the running of the household (see below);

4) to be part of an informal village support network with other poor families (see below);

5) to be illiterate, but to want to educate their children; 6) to be landless or to have a small amount of unproductive land [see Lipton 1985], and to be irregularly employed;

7) to have relatively few assets or exchange entitlements

${ }^{6}$ There is, however, a large survival literature from the Second World War, much of it by labour camp prisoners - Eugenia Ginzburg, Bruno Bettleheim and Primo Levi, for example - and inhabitants of cities under siege, such as Olga Friedenberg and Vera Ibner on Leningrad. Interesting parallels could be drawn between strategies used by (intellectual) survivors and those used by the rural poor in 
[Lipto11 1985; S•n 1982];

8) to be in clinical dinger of undernutrition, and to spend at least 80 per cent of their income without achicving 80 per cent of minimun nutritionil requiremınts [Lipton 1983a];

9) to have illness or have liad recent illness in the household, and to be physically weak;

10) to be isolated in locational terms, and in terms of village power [Chambers 1983:111-4];

11) to be female headed [Gulati 81:170; Mcncher 1985:364: Begum 1985:231], and/or have large, young families [Lipton 1983c];

12) not to belong to any political party (see below); and,

13) to spend substantial household time on comnion property resource activities [Jodha 1986].

Many of the poorest houscholds are therefore likely to be landless labourer households witl a female, physically weak, or often ill main earner, and/or several young children. This is a rough checklist which could be added to, and is dependent on regional variations, but the more of these indicators there are located in a household, the greater chance that this household is among the poorest. A single statistical indicator of poverty cannot expect to capture the depth and variety of the lifestyle of the poorest at village level, ${ }^{7}$ nor can a concentration on the formal village economy; and policy is liable to be misdirected if based solely on such indicators.

\section{STRATEGIES FOR SURVIVAL, AND POWER}

Some survival strategies, such as taking debts, selling assets, and migration, are relatively well recognised. Others identified during the fieldwork are less so, and will be presented here: use of common property resources (CPRs); changes in eating and food preparation; share-rearing of livestock; and mutual support networks. All these are mainly undertaken by women and children, and challenge the dominant view that the poor are passive. While extreme crises such as famine are met by sequences of survival strategies [Corbett 1988], everyday survival strategies vary in relative importance at different times. They also interlink, but can for the time being be described separately.

\section{1) Use of Common Property Resources}

Strategies using CPRs includes gleaning, collection of fuel, and collection of wild foodstuffs.

\section{Gleaning}

Gleaning in Fonogram had been restricted by two bad

The inadequacies of statistical measurement of poverty are discussed at further length in Beck [1988]. agricultural vears due to flooding, and also by those who owned the fields. However, 17 out of 22 respondents reported gleaning whenever there was time, and that this was an activity carricd out mainly by children. In the remaining five houscholds there were either no children, or respondents were out all day at work. Estimates of the anounts gathered rallged from 'a handful', to $12 \mathrm{~kg}$ an acre, to $5 \mathrm{~kg}$ for' a good day, to $25 \mathrm{~kg}$ a season. This can be compared to the amount of government aid received after the two floods - noost respondents reported receiving 2-3 kg of wheat each year from the government. ${ }^{*}$

\section{Collection of Fuel}

All respondents who could gathered twigs, brancles, leaves and cow dung. This collection was seasonal, mainly in the winter and sumner, but not in the rainy season, as then no leaves fall and no-one pastures their livestock - a seasonal problem for the poorest not often noted. Most respondents did not quantify in their own minds the time spent on gathering fuel, but al common remark was that one person working for a morning (three to four hours) could collect enough to last for two days. For the most part where there are children in the hosuehold, they do the gathering. ${ }^{9}$ Most of the households' fuel requirements were niet in this way, although all respondents said that the availability of CPR fuels had steadily decreased over time because of pressure on resources.

Jodha [1975:1620, fn 14], Caldwell [1986:683], Dasgupta [1987: 106-7] and Howes and Jabbar [1986] provide comparative South Asian material on the importance of gathered fuel to poor houseliolds, and Jodha [1986:1174-5] has estimated that poor households in 21 districts of seven states in dry tropical western and southern India, meet 66-84 per cent of their fuel requirements from CPR activities, a finding that is mirrored in Fonogram village.

\section{Gathering of Wild Foods}

Almost all the respondents gather and eat wild foods, and gathering is done whenever and wherever possible and necessary - a point stressed by all respondents. Reported wild plants gathered were 'shojina pata' (horse radish), 'kolmi pata' (an 'edible aquatic plant'), 'neem pata' (margosa), 'kochu' (an 'esculent edible root'), 'dumur' (fig), 'pather pata' (jute leaves), and 'helingsha' (a kind of watercress). Crow [1984:1756],

\footnotetext{
${ }^{8}$ Sengupta [1978:7] has described Santal children collecting grain from rat holes and other kinds of gathering in Birbhum district of West Bengal. For Bangladesh, see also Siddiqui [1982:358] for gleaning. Cain [1977:204, 209] who refers to children opening rat holes and gleaning, and Begum [1985:235] for regional differences in gleaning practices.

'Children also collect snails to feed to poultry. Date palm leaves are left on the side of ponds with most of the leaf submerged, and the snails crawl onto the leaves. Other livestock fodder is also gathered, as are various household materials, and livestock are taken regularly to graze on fallow land.
} 
Greenough [1982:231], Currey [1981:128], and Rahaman [1981:137] all report consumption of 'kochu' by poor families in famine conditions in Bengal and Bangladesh. These wild foods cannot be consumed too often or they will cause health problems.

Children also gather fruits such as plums, tamarind and mango, and Sengupta [1978:9] describes 'landless families living on jackfruit or mango in Malda and Coochbehar (West Bengal)'. All this again suggests the inadequacy of the use of income or outlay to measure poverty. ${ }^{10}$

Jodha [1986] estimates that poor households spend 10-20 per cent of their time on CPR activities, generating 15-25 days of work per household every three weeks in this way. Given this cumulative importance of CPRs, it might be worth questioning Lipton's assertion [1983a:48], that 'Hungry Indians are poor, and attempts to solve their food problems by (e.g.) persuading them to gather and cook more wild food and vegetable tops tends to neglect collection and cooking costs'. It seems poor, hungry people are already active in this area, and do not need to be persuaded to gather.

\section{2) Changes in Eating and Food Preparation}

Changing patterns of eating and food preparation are less well known as a coping strategy than gathering. Spending by the poorest in Fonogram is irregular ("whenever money or a loan is available we get food' as one respondent put it), and so are their eating patterns.

'The stomach won't understand unless it gets rice' one respondent told me. But when ordinary rice is not available, several other substitutes are. Respondents reported eating 'khud' - broken rice grains, about 25 grams of which come out of $1 \mathrm{~kg}$ of sieved rice, and which are sold only in the village, usually by better-off families. 'Khud' costs about two thirds of the price of the cheapest market rice. This can be fried with oil and salt and alleviates hunger. They also reported drinking the water left over after rice had been boiled in it ('bhater fan'), which is usually given to livestock, and eating parts of chaff left after threshing. Greenough [1982:233] also notes the consumption of rice water during the 1943 Bengal famine.

Certain foods fill the stomach better than others. Several respondents said that they ate 'par routi' (leavened bread) and then drank a lot of water to fill the stomach, or 'gola routi' (flour mixed with water and fried like an omelette), which was considered more filling than 'chapati'. 'Fatter' varieties of rice

\footnotetext{
${ }^{6}$ Most of the comparative literature on gathering wild foods deals with famine situations rather than periods of regular stress. For a list of famine foods in Nigeria. see Watts [1983:432-3] and for a more detailed discussion in Ethiopia, Rahmato [1988:8-10]. For a review of ot her literature see Longhurst [1986:32], and for a genera! discussion, Leakey [1986].
}

were preferred, as they were considered to give more energy; those doing manual work thought that they needed a fatter grain than 'babus' (gentlemen) who wear wristwatches and trousers and sit in offices all day, and who prefer thinner varieties. Salt tea is also commonly taken, as sugar or molasses is too expensive, as is 'pan' as an appetite suppressant.

A common response to the question of eating patterns after the two floods was: 'we made one meal stretch into two', 'we ate one day and fasted the next', or 'we ate once a day and got by like that'. Jodha [1975:1620, fn 15, 1978:A38-9]. Caldwell [1986:688] and Van Schendel [1986:43] all report regulation of consumption as a strategy for dealing with food shortage. Sleeping and fasting when no work was available, was quite common. Lipton [1983a:32-3] and Dirks [1980:23] consider the nutritional side of this strategy, and Hartmann and Boyce [1983:172] and Harari and Garcia-Bouza [1982:35] also give examples for Bangladesh and India.

Eight of the 22 respondents in Fonogram said that if they received a little more money they would save it for the next day rather than use it immediately to buy food. There is some evidence to suggest that poor people do plan for the long-term future by regulating consumption of food to protect assets. A connection between 'voluntary' cuts in consumption and protection of assets may partly explain the finding of a longitudinal study over five years in four districts of the Kosi hill area of Nepal [Nabarro, Cassels et al. 1987] that land sales decreased but nutritional status did not improve. If poor households do protect assets by resorting to cuts in consumption, and where, as in Eastern India, there is discrimination against females [Harriss 1986], policies and programmes to provide assets for the poor may perversely mean that women get less within the household.

Cuts in consumption are an enforced part of the lifestyle of the poorest. Within the narrow confines in which they found themselves, respondents had developed an expertise in food management. There were, however, several stories about irresponsible spending by some of the poorest households, and there is no reason to suppose that irresponsibility in spending is a characteristic solely of the rich.

One respondent, a widow with four young children and irregular income, when asked how she remained healthy on what seemed an inadequate diet, vividly described the different ways in which rich and poor people eat. She mimicked how rich persons would have five or six dishes of different foods in front of them and would take a little from each, turning up their noses at most of the dishes as being too spicy or too sweet, and therefore ending up eating only a small quantity; whereas poor persons would eat the whole of whatever was put in front of them, whatever the quality or quantity. This was a reminder that it is not 
only the rich who have views about how and what poor poople eat.

\section{3) Share-Rearing of Livestock}

Twenty of the respondent houscholds had some livestock. the two exceptions being unable to kcep any as they had no courtyard to their houses. Of these 20 . seven werc share-rearing livestock and five others had share-reared in the previous five ycars. One other household wanted to share-rear but conld not because of unavailability of animals. Five mentioned difficulty in getting animals.

The system is known locally as 'poussani'. which means to rear. The most common arrangement is that a houschold will raise a female goat. cow. duck or chicken given to them by another. nsulally richer. houschold. After the animal has given birth twice. the first born and the mother are returned to the owner. and the rearer keeps the second born. In the case of a male animal, the proceeds after sale are divided equally between owner and rearer.

Livestock can be vitally important in sustaining poor households during periods of crisis [see Chambers 1983:129-30 for examples]. but share-rearing and its importance to the poor have tended to be overlooked by researchers. Yet this system was operating in Bengal in the 1930s and 1940s, as Cooper [1984:80] comments: "The landlord ensured that the sharecropper was provided with the means of production without actually bearing the costs of raising the livestock. even increasing his own stock', "1

Share-rearing. in various forms, is common throughout South Asia today, and elsewhere. ${ }^{12}$ Jodha [1986:1180. fn 10] refers to how large farmers sharerear out of the poor. throughout seven states of western and southern India:

Though varying in its extent. the practice of 'salvaging' unproductive animals was observed in practically all the study areas. Large farmers gave their unproductive animals to the poor for maintenance as it was clearly costly to maintain them ... When such animals became productive

\footnotetext{
"Sunil Sengupta has told me that 'poussani' was operating several generations before the 1940s.

${ }^{12}$ For references to share-rearing (technically known as agistment) in villages in Bangladesh see Howes and Jabbar [1986:24-5]. Hartmann and Boyce [1983:163]. Westergaard [1983:52-7]. Chen [1983:3,148,163]. Siddiqui [1982:357]. Van Schendel [1981:90.112. $167.172 .331 \mathrm{fn} 7$ ] and Jansen [1986:44]. For India. as well as Jodha see Epstein ot al. [1983:121]. Bose [1984:100, 104]. and Dasgupta [1987:110]. Paul Seabright has told $\mathrm{me}$ the system also operates in Tamil Nadu. For West Africa see White [1986:24 (Niger)], and Chambers $\mathrm{ct}$ al, eds. [1981:86 (Mali)]. and for Ethiopia. Rahmato [1988:16]. In Botswana, the system is known as 'mafisa'. Andrew Turton has told me that it operates widely in Northern Thailand. Jon Rigg has referred me to agistment in the highlands of Papua New Guinea and pointed out that government "buffalo banks" using agistment system are common in Thailand. and David Nabarro has told me that the systcm is found thronghout Nepal.
}

they were returned to the large farmer and net additions to the valuc of sich animals (after becoming productive) were shared by the two parties. Depending on the type of animal ... the terms and conditions governing this practice differed from region to region. In areas like Gujarat and Rajasthan such herding was an important sourec of income for the rural poor.

And Blaikie et al. [1979:64] comment on share-rearing in West Central Nepal. noting that in several locations visitcd all the brecding of oxen wals undertaken on this basis by labouring and artisan households. Bcaring in mind that share-rearing potentially bencfits both owner and rearer. it is perhaps not surprising that it is so widespread.

\section{4) Mutual Support Networks and Power}

Power relations in the village from the poor person's perspective would scem to be central in understanding the problem of poverty, but this perspective is usually avoided in favour of others less controversial. As Breman [1985:34] has observed:

In India there is a great scarcity of literature in which those living in the lowest echelons of society themselves speak ont. For South Gujarat the region towards which my research has been directed for more than two decades now. I do not know of a single publication in which exploitation and repression is reported on the basis of experience from within.

I now proceed to deal with power relations with an awareness of the paradox involved in such research - that these relations are central to village life. but an area around which the researcher can only skirt.

Discussions were held with the respondents on the reasons for their poverty. how it feels to be poor. the characteristics of rich and poor people. whether the poor help each other or are helped by the rich. whether the rich cheat the poor why the poorest do not get organised. and the importance of self respect. Respondents themselves made the division into rich and poor - 'gherastao' and 'gorib'. (For a similar definition of village differentiation based on poorer villagers' views. [see Van Schendel. 1981:90].

None of the respondents belonged to a political party. and only one was familiar with government laws on sharecropping or homestead rights. In a wider. more formal sense, therefore, respondents could be considered apolitical. But their lack of involvement in formal politics did not mean that they did not hold strong 'political' ideas about what was happening in their village.

As to how most respondents viewed their poverty. most replied in this manner: 'Do you think I like being poor - don 't you think I'm unhappy being poor?'. Poverty also meant a loss of respect which was worse 
than hunger; apart from three who differed, all other respondents did not hesitate in saying that for them respect was more important than food, and that 'without respect food won't go into the stomach'. If' this feeling is widespread among the poor in India, then planners' and academics' exclusive interest in income and nutrition is inadequate for understanding poverty.

When asked whose fault ('doash') it was that they were poor, all 22 respondents saw their poverty in terms of a similar apolitical causality - either they had lost their land or other assets, or were unable to work, or had not inherited any property, or they said that the population was increasing whereas land was not. or blamed the weather, or bad luck. As one woman put it: 'We are poor because we have no land and my husband can't work ... We had six 'bighas' of land before and plough cows and my husband could work five years back'. Not one of the respondents thought their poverty was the fault of the rich in the village.

At the same time, respondents had definite ideas about the characteristics of the rich (and it should be remembered that it is Fonogram's poorest villagers' views that are presented here). Two respondents thought rich people helped poor ones, but the rest were adamant that they received no help ('shahajo') from the rich. About this, there was almost unanimous animosity. As one elderly widow put it:

Rich people don't mix with the poor at all - even if we were dying and called them they wouldn't come. $\mathrm{J}$. is going by motorcycle, $\mathrm{A}$. by lorry and $\mathrm{H}$. by cycle. I'm going by foot, shoeless. In the rainy season the rich eat well, but we have to eat fig leaves and get sick.

And a young landless labourer said more vividly: 'Rich people are drinking poor people's blood, talking to them but not giving them anything'.

Almost all agreed that rich people cheated poor people by giving too low wages, by making them work too hard, or giving too low prices for land or other assets. But no respondents made a causal connection between their own poverty and others' wealth. As allother landless labourer said: 'It's my own fault we are poor, not the fault of rich people'. ${ }^{13}$ However, the poor did not stop at insulting the rich. One newly wealthy family in particular, as well as other richer families, was the subject of theft and attack. Theft of pump sets and power lines were also common in the three years after 1985, when electricity had been introduced into the area. No-one familiar with the long history of 'peasant' protest in Bengal will be surprised at the use of these 'weapons of the weak'.

Equally, almost all respondents thought that pour

\footnotetext{
${ }^{13}$ Arens and Van Beurden make a similar point about "class consciousness' in Bangladesh [1977:77]. For different views see BRAC [1979] and Epstein et al. [1983:127]. See also Van Schendel [1981:92].
}

people helped and did not cheat each other. This help consisted mainly of small loans of either money, rice or other edibles. This was despite the fact that there had been some disputes between the respondent households and between household members over relatively large loans and other serious matters such as 'theft' of land. ${ }^{14}$ While loans between poor households were considered as help, loans from rich to poor were not: everything depended on the attitude of the lender. $K$. Jansen [1986:19 and 25: table 5] has also commented on the importance of intra-family loans in six villages in Noakhali District of Bangladesh, where such loans make up 32 per cent of total village lending and were mainly used for household subsistence purposes.

One of the questions asked of respondents was why poor people did not cooperate with each other. The example was given of forming a buying cooperative which would cut prices at the local market, as buying could then be done in bulk. The most common reply was that there was no unity among the poor, that they all got money at different times, and that those who received money first would try to buy the best quality goods. While the rich were powerful, the poor were too jealous of each other to work together. The word jealousy or envy ('hingsha') was used several times. As one landless labourer said: 'The poor work together sometimes when farming. But they can't work together usually because of lack of resources. They can't go shopping together because some people go later and some earlier'.

Although adequate resources may be necessary if poor people are to cooperate rather than compete, it did seem as if there was a strong tradition of mutual support amongst the poorest in the village, based on the informal system of loans, and that they were also united in their animosity towards the rich, an animosity that was often strongly voiced.

There is an extensive literature on mutual support systems among the rural poor. Caldwell [1986:694] points out from his work in Karnataka the importance of marriage networks as a central mechanism in the insurance system against disaster', and Jiggins [1986: 16] notes: 'One feature which stands out is the resilience of female household networks to seasonal stress and calamity; far from being among the most vulnerable, more critical study of the advantages of their organisational and economic flexibility may show that they are the "survivors".'

Other recent evidence [see Van Schendel 1986:48-9; Howes and Jabbar 1986:25 and Dasgupta 1987:114 for South Asian material, and see also footnote 15]

\footnotetext{
14 A subjict not discussed here is intra-family sale of assets and land leading to greater intra-family differentiation. which may be common in West Bengal. Poverty and violence are closely interlinked. and there were many examples of intra-family violence in Fonogram.
} 
suggests that Lipton's assertion [1983a:66], may be open to question: 'Traditional rural compensations, the inst itutions of mutual help, were often exaggerated, and anyway are under pressure from both population growth and economic modernisation'.

Respondents in Fonogram reported going from house to house asking for 'khud' and 'bhater fan' as well as for building materials. But the main kind of loans between poorest households was in the form of small amounts of money or foodstuff, which all respondents mentioned giving or taking. Other forms of mutual support were looking after children or livestock. There is a complicated system of exchange, borrowing, receiving and giving in Fonogram village. But a distinction is made between a 'loan' between poor people which is an expression of support, friendship and solidarity, and a loan begged from either another poor person or someone better-off, which involves a subordinate relationship.

\section{Policies to Support Poor People's Strategies}

What scope is there for policies to support these strategies of the poor? This can only be answered in context. Other strategies such as migration and sale of assets may be more the concern of men, but those discussed here focus mainly on the home and women and children's labour. Various factors affect these strategies. The cultural environment is one determinant of consumption patterns [K. Jansen 1986], and also of whether or not poor women go outside the house to work. Strategies are perhaps more likely to vary by gender and ability than by age. The political setting in which they find themselves will, obviously, also influence the actions of the poorest. Mechanisation may affect strategies such as gleaning [Scott 1985:1189]. Environmental factors will also affect how the poorest people survive; those living in an area with a high person/land ratio and scarce CPRs may have strategies very different from those living in the low person/land area described by Richards [Richards 1985]. There are also overt and covert political strategies, with which the student of English agrarian history is familiar - trade union activity, 'spontaneous' violence, or breaking of agricultural machinery. Individual and community strategies for survival may also differ. Given this variety of possible actions by poorest people, perhaps the most useful way of analysing survival strategies would be to identify those

\footnotetext{
${ }^{15}$ See also Longhurst for Northern Nigeria [1986:30], Toulmin for Mali [1986:66], and Rahmato for Ethiopia [1988:7]. Dirks [1980:113] has suggested that such networks will break down in times of extreme stress. Splitting of families is also common. Lest these strategies be thought exclusive to the Third World, see McKee [1987:113] on households with unemployed males in present day Britain. Neighbours were variously described as providing help with household goods, furniture, child-minding or childrens clothes. Women's networks were often the key to these exchanges.'
}

most likely to be supported by NGOs or governments, and to consider liow poor people's efforts and those of outsiders can be linked.

Any consideration of policy in eastern South Asia has to take into account a high degree of centralisation of planning, a male-dominated and inefficient bureaucracy, and an overburdening of extension and villagelevel workers [for the latter, see NIRD 1985:80-1, 28691]. Scarcity of land and CPRs are also major constricting elements for policy, as are the competing interests of landless labourers, sharecroppers and marginal farmers. Also, the strategies of the poorest described here, because they are part of an informal, and sometimes invisible, economy, may not be as amenable to government support as are those more informal agricultural activities carried out by small farmers and described by Richards and Watts. The possibility of 'reformist' outsider policy should be viewed in the light of these constraining contexts.

\section{Use of CPRs and Famine Foods}

Use of CPRs is a thorny policy area. Changes in policy priorities towards an interest in CPRs can be seen in a recent World Bank publication which deals briefly with how rural households try to cope with transitory food insecurity [World Bank 1986:26]:

In extreme cases in India, Ethiopia and Bangladesh, the starving eat a drought resistant legume, known as kessari dal, even though it can lead to paralysis. Since poor families draw on these famine foods in times of need, more research is needed to identify all sources of such foods, to understand fully how they are used, to determine what can be done to ensure their availability during periods of stress, and to develop a non-toxic variety of kessari dal or a processing method that will eliminate the toxic effect.

Indigenous methods of detoxification available for other plants [see Corkhill 1949:7; Bhandari 1974:77, and Leakey 1986:38 ] suggest that it may be possible to develop such detoxification processes using village knowledge. A shift in research priorities towards 'famine foods', as suggested, would surely benefit the poorest who are the main users of such foods.

\section{Share-Rearing of Livestock}

The system of share-rearing livestock described above raises questions about the Government of India's central poverty alleviation programme, the Integrated Rural Development Programme (IRDP), which provides subsidy and loans to the poor to enable them to buy assets - often livestock. Problems with IRDP include leakages away from intended beneficiaries, unavailability of good quality livestock at reasonable prices, and lack of green and dry fodder [Rath 1985; Singh 1985:335; Seabright 1987]. 
IRDP is based on top-down planning approaches - a scheme is devised, beneficiaries identified, and loans and subsidies given. At the same time the indigenous share-rearing method of loaning livestock that is widespread throughout South Asia has been ignored by planners, who may not even be aware of its existence. As share-rearing can benefit both (richer) loaner and (poor) borrower, it presents a 'gap' where reformist policy can feasibly build upon strategies used by the poor. Most respondents in Fonogram village said that it had become increasingly difficult to find livestock to share-rear. If this scarcity is widespread (and the demand for livestock for the IRDP may be one cause of scarcity), incentives may be necessary to persuade livestock owners to lend perhaps in the form of loans to the rearer to buy good quality feed. Backing up and improving this indigenous method might help reduce the problem of too few good quality livestock, and market 'imperfections' that have meant IRDP recipients purchasing overpriced, poor quality animals.

\section{Mutual Support Networks}

To move to mutual support networks, various commentators have suggested agricultural cooperative development as the next step forward for the Communist Government of West Bengal. But little attention seems to have been given to either agricultural labour union activity or more informal kinds of poor people's organisation and cooperation. Yet BRAC has shown in Bangladesh [Chen 1983] that it is possible to organise groups of poor landless women, using their skills for productive work, as long as the groups are homogeneous, and there is an economic incentive for the women to participate. While the poorest may 'exploit' each other (partly because they have no other choice than to do so), it does seem that there is a strong existing indigenous system of cooperation among the poorest, based partially on an animosity towards the rich, that could act as a basis for the formation of groups to receive loans. Yet Government intervention in this area has up until now been at best unpromising. ${ }^{16}$

\section{Policy in General}

In the case of policy in general, much depends on the view the policy maker takes of the poor person. This is particularly relevant in the case of nutrition and poor people's preferences in food. Rich people's interest in what poor people eat is nothing new. Attempts to control the diet of the poor for political reasons date back, in Britain, at least until the late eighteenth

\footnotetext{
in For the failure of such groups to take off under the Government's Development of Women and Children in Rural Areas programme in Bankura and Purulia districts of West Bengal, see Ghatak [1985]. who attributes failure mainly to inefficient administration.
}

century [Hammond and Hammond 1948:119]. Historically, little research on nutrition has looked at the preferences of poor people and how these might be included in nutrition policy, nor the political consequences of conducting nutritional studies. One of the major debates about poverty in India - on the level of nutrition and income necessary for a poor person to survive - has followed this historical pattern. This debate has focused almost exclusively on 'scientific' and statistical estimates, and various participants have performed various forms of statistical acrobatics to support their argument. Practically no-one has asked poor people how much they think they need to eat, or attempted to measure this against 'scientific' estimates. Yet poor people's preferences might be vitally important in deciding on the type and quality of food to be dispensed in times of emergency, or through ration shops. This form of 'intellectual colonialism' - viewing the poor as those to be measured, weighed and planned for, rather than as people who make choices and decisions - needs to be challenged by empirical research which accepts that the poor have a voice.

\section{CONCLUSION}

This article has attempted to show that the poorest people, especially women and children, rather than being passive or apolitical, are active in their household survival strategies. While, in a South Asian context, the poorest live in an oppressive social systein, which partly defines their actions, they also exploit that system for their own benefit. Measures to support and improve their present strategies may be of more use to them than externally imposed schemes (which include intermediate technology such as solar power or biogas), the benefits of which are likely to be appropriated by those at village level who have more power.

Although more comparative empirical evidence is needed to argue against the dominant paradigm that the poor are passive or followers, there is also a need for outside researchers to be aware that their solutions to poverty are likely to be marginal to its main causes. Equally, those who have never been active in cooperatives or trade unions should perhaps be wary of advising poor women and men to join or form such organisations. While poor people may want political support and sympathy, they may not want advice. So it may be that research concerned with the rural poor should be less about identifying their characteristics and giving advice, and more about listening to and presenting poor people's views. As one poor woman in Mymensingh District, Bangladesh, told someone who suggested she cook more green leafy vegetables [McCarthy 1984:55]:

Don't worry about what I feed my family. You just give me some money and I will take care of it. You 
don't have to assume that $l$ don't know what to feed my family. The problem is that 1 happen to be poor. and if you can't do anything about that then get out of here. Don't waste my time.

Acknowledgements: Thanks arc due to Datoud Knobi. Maya Rani Lodh and Kalipodo Pal who assisted in field level interviews, and to Robert Chambers. Graham Chapman. Cathy Nesmith and participants of' the IDS workshop on "Coping and Vulnerability" for comments on a first draft.

\section{References}

Arens. I. and Van Beurden. J.. 1977. Nhagrapur: Poor peasams and women in Bangladesh. Arons and Van Beurden. Amsterdam, (distributed by Third World Publications)

Arnold. D., 1984, Famine in peasant consciousness and pcasant action in Madras 1876-8 in R. Guha (ed.). Suhahern Sudies 3. Oxford University Press

Bandopadhyay. N.. 1983. Evaluation of LandReform Measures in West Bengal: a report. Center for Studies in Social Sciences. Calcutta

Beck. T. 1988. "Bevond enumeration": survival of the poorest and poverty measurement in India". paper given at IDS. Sussex, and the Institute of Commonwealth Studies. London

Begum. S.. 1985. 'Women and technology in rice processing in Bangladesh', in Women in Rice Farming. IRRI/Gower

Bhandari, M. M. 1974. 'Famine foods in the Rajasthan Desert', Economic Bolany, vol 28 no 1

Blaikie, P. M. el al., 1979, The Suruggle for Basic Needs in Nepal. OECD. Paris

Bose. P. K.. 1984. Classes in a Rural Socien: A Sociological Suldy. Ajanta, Calcutta

BRAC. 1979. Peasam perceplions: famine. Bangladesh Rural Advancement Committee, 66 Mohakhali C.A.. Dhaka 12

Breman. J., 1985. 'Between accumulation and immiseration: the partiality of field work in rural India'. Journal of Peasan Sulies. vol 13 no 1

Cain. M. T. 1977. 'The economic activities of children in a village in Bangladesh $:$ Population and Development Review. vol 3 no 3

Caldwell. J.. el al.. 1986. 'Periodic high risk as a cause of fertility decline in a rural environment: survival strategies in the 1980-83 South Indian drought '. Economic Development and Culiural Change. vol 34 no 4

Chambers. R.. 1983. 'Rural Developmenl: Pulting the Lasl Firsi, Longman

-1988. 'Poverty in India: concepts, research and reality'. Discussion Paper 241. IDS, Sussex. January

-el al.. (eds.). 1981. Seasonal Dimensions io Rural Povery. liances Pinter, London

Chen. M. 1983. A Quicl Revolmion: women in wansinon in rural Banglakesh. Salenkman

Cooper. A.. 1984. 'Sharccropping and Sharccroppers' Struggles in Bengal. 1930-50. IDPhil thesis. University of Sussex

Corbett. J.. 1988. "Faminc and houschold coping stratcgics World lo'relopme'th vol 16 no 9. pp 1099-1112

Corkhill, N. C.. 1949. Dictary change in a Sudan village following locust visitation". 1frica. vol XIX no 1

Crow, B.. 1984. 'Warning of famine in Bangladesh'. Ficonomic and Political Weckly (EPW), no 40. Oct. 6

Currey, B.. 1981. "The famine syndrome: its definition for relicf and rehabilitation", in John R. W. Robson (cd.). Famine. Its Causes, Effects ahd Managemem., Gordon and Breach

Dasgupta, M., 1987. "Informal sccurity mechanisms and population retention in rural India'. Ecollomic Developmen and Culmaral Change, vol 36 no I

Dirks, R., 1980, 'Social responses during severe food shortages and famine'. Current Amhropologl', vol 21 no 1

Epstein. T. S. er al. 1983. Basic Necds Viened from Above and Below: the case of Karnataka Stale. India. OECD. Paris

Ghatak. M. 1985. 'Devclopment of women and children's rural areas of Bankura and Purulia districts: an evaluation? CRESSIDA Calcutta. (mimeo)

Greenough. P.. 1982, Prosperity and misery in modern Bengal. OUP. Delhi

Gulati. L. 1981. Profiles in Female Poverly. Hindustan Publishing Corporation (India), Delhi

Hammond. J. and Hammond. B., 1948. (1st ed. 1912). The Village Labourer. Guild Books

Harari. D. and Garcia-Bouza. Jorge, 1982, Social Conflict and Developmenl: Basic needs and survival surategies in four national sellings, OECD. Par is

Harriss. B. 1986. 'The intrafamily distribution of hunger in South A sia', paper given at the Institute of Commonwealth Studies postgraduate seminar series. October

Hartmann, B. and Boyce. J. K. 1983. A Quiel Violence; vien. from a Banglalesh village. Zed Press, London

Howes. M. and Jabbar. M. A., 1986. 'Rural fuel shortages in Bangladesh: the evidence from four villages'. Discussion Paper 213. IDS, Sussex

IDS. 1986. 'Seasonality and Poverty'. IDS Bullerin vol 17 no 3. July

Jansen. E.. 1986. Rural Bangladesh: competilion for scarce resources. Norwegian University Press (distr. OUP) 
Jansen. K.. 1986. Survival strategies of the rural poor in Bangladesh". Centre for Development Research. Copenhagen. (mimeo)

Jiggins. J.. 1986. 'Women and seasonality: Coping with crisis and calamity' in IDS. op. ciil.

Jodha. N. S.. 1975. Famine and famine policies: some empirical evidence . $E P W$. no 41 . Oct. 11

-1978. 'Effectiveness of farmers' adjustments to risk'. EPW. Review of Agriculture no 26. June

-1986. Common property resources and rural poor in dry regions of India'. EPW no 27 . July 5

Kynch. J. and Sen. A. K.. 1983. 'Indian women: well-being and survival'. Cambridge.Journal of Economics. vol 7 nos $3 / 4$

Le:1key. C.. 1986. Biomass. man and seasonality in the tropics: in IDS. op. cil.

Lipton. M.. 1983a. 'Poverty. Undernutrition and Hunger'. World Bank Slaff Working Paper no 597. World Bank. Washingt on DC

-1983b. 'Labour and Poverty". WBSWP no 616. World Bank. Washington DC

$-1983 \mathrm{c}$. 'Demography and Poverty'. WBSWP no 623. World Bank. Washington DC

-1985. 'Land Assets and Rural Poverty'. WBSWP no 744. World Bank. Washington DC

Longhurst. R.. 1986. 'Household food strategies in response to seasonality and famine. in IDS. op. cir.

McCarthy. F.. 1984. The target group: women in rural Bangladesh in E. J. Clay and B. B. Schaffer (eds.), Room for Manoeuve: an Exploralion of Public Policy in Agricullural and rulal Development. Gower

McKee. L.. 1987. 'Households during unemployment: the resourcefulness of the unemployed. in J. Brannen and G. Wilson. (eds.). Give and Take in Families: Siudies in resource disiribulion. Allen and Unwin

Mencher. J.. 1985. 'Landless women agricultural labourers in India: some observations for Tamil Nadu. Kerala and West Bengal'. in Women in Rice Farming, 1RR1. Gower

Nabarro. D..Cassels. C..el al. . 1987. 'The impact of integrated rural developments: The Kosi Hill Area Rural Development Programme. East Nepal'. Department of International Community Health. Liverpool School of Tropical Medicine. October

N1RD. 1985. Administrative arrangements for rural development: proceedings of the national workshop held at the National Institute for Rural Development (Hyderabad). Government of India Publications

Rahaman. M. M.. 1981. The causes and effects of famine in the rural population: in John R. K. Robson (ed.). Famine: its causes and management. Gordon and Breach

Rahmato. Dessalegn. 1988. Peasanı Survival Siralegies. International Institute for Relief and Development. Food for the Hungry International. Geneva
Rath. N.. 1985. Garibi Hatao: can IRDP do it?' EPW. no 6. Feb. 2

Richards. P.. 1985. Indigenous Agriculutral Re'olution. Hutchinson

-1986. Coping wih Hunger. Allen and Unwin

Scott. J.. 1985. Weapons of the Weak: everyalay forms of peasam resisiance. Yale U.P.

Seabright. P.. 1987. '1dentifying investment opport unities for the poor. evidence from the livestock market in South India. Department of Economics. Cambridge (mimeo)

Sen. A. K.. 1982. Poverly and Famines. Clarendon Press. Oxford

-1983. 'Poor relatively speaking". Oxford Economic Papers. 35

Sengupta. S.. (with M. G. Ghosh). 1978. State intervention in the vulnerable food economy of India and the problem of the rural poor. paper for workshop on problems of public distribution of foodgrains in Eastern India. March 7-9 (mimeo)

Siddiqui. K.. 1982, 'The political economy of rural poverty in Bangladesh: National Institute of Local Government. Dhaka

Singh. K.. 1985, Eradicating rural poverty: lessons of IRDP experience'. in NIRD. op. cil.

Toulmin. C.. 1986. Access to food. dry season strategies and household size amongst the Bambara of Central Mali. in IDS. op. cil.

Townsend. P.. 1985, 'A sociological approach to the measurement of poverty - a rejoinder to Professor Amartya Sen, Oxford Economic Papers. 37

Van Schendel. W.. 1981. Peasant mobility: the odds of life in rural Bangladesh: Van Gorcum, Assen

-1986 , Self rescue and survival: the rural poor in Bangladesh:. Joumal of Soulh Asian Siudies, vol 9 no 1

-and Faraizi. A. H., 1984, Rural labourers in Bengal 18801980. Comparative Asian Studies Programme. Erasmus University. Rotterdam

Watts. M.. 1983. Silen Violence: food, famine and peasantry in Norlhern Nigeria. University of California Press

Westergaard. K.. 1983. Pauperizalion and rural women in Bangladesh: a case sıudy. BARD. Comilla

White. C.. 1986, Food shortages and seasonality in WoDaaBe communities in Niger'. in IDS. op. cit.

Whitehead, A.. 1984. 'Women's solidarity - and divisions among women. IDS Bullerin. vol 15 no I

World Bank. 1986. Poverly and Hunger: issues and oplions for food securily in developing countries. World Bank. Washington DC 